\title{
A NEW SPECIES OF CLEISTES (ORCHIDACEAE, VANILLOIDEAE) FROM COLOMBIA
}

\author{
MARTA KOLANOWSKA ${ }^{1} \&$ DARIUSZ L. SZlachetKo
}

\begin{abstract}
Cleistes cuatrecasasii Kolan. \& Szlach. sp. nov. from the Pacific slope of the Colombian Andes is described and illustrated. Information about its habitat and distribution is provided, and the taxonomic affinity of the new species is briefly discussed.
\end{abstract}

Key words: Andes, biodiversity, Nariño, taxonomy

Marta Kolanowska \& Dariusz L. Szlachetko, Department of Plant Taxonomy and Nature Conservation, University of Gdańsk, ul. Wita Stwosza 59,80-308 Gdańsk, Poland; e-mail: martakolanowska@wp.pl

\section{INTRODUCTION}

The Neotropical genus Cleistes Rich. ex Lindl. was described by Lindley (1840) to separate plants characterized by the presence of longitudinal crests or lamellae on the lip, but its species usually have been united within Pogonia Juss. (Schweinfurth 1958; Schultes 1960; Foldats 1970; Williams et al. 1980). Subsequent morphological studies (Dressler \& Dodson 1960; Garay 1978; Szlachetko \& Rutkowski 2000) and molecular research (Cameron 2003) clearly indicated the generic distinctiveness of Cleistes.

As currently recognized, the genus embraces plants characterized by sessile leaves remotely arranged along the stem. Usually a few showy resupinate flowers are produced per plant. Both sepals and petals are free; the sepals are subsimilar, usually longer but narrower than the petals. The lip is entire or 3-lobed, always ornamented with crests and/or lamellae, with two clavate basal projections. The erect, elongate, slender gynostemium is often \pm sigmoid. The column foot is absent. The incumbent, ellipsoid anther is dorsiventrally flattened, motile, and 2-chambered. Four oblong-ovoid to narrowly cylindrical pollinia are produced. Staminodes

\footnotetext{
1 Corresponding author
}

are wing-like, connate partially with the filament, with the style forming a prominent pocket hiding the basal part of the anther (Szlachetko \& Rutkowski 2000).

Nowadays over 50 Cleistes species are recognized (Christenson 1992; Campacci et al. 2011; Pansarin 2004; Pansarin \& Barros 2008; Szlachetko \& Baranow 2012). The geographical range of the genus extends from Peru to Costa Rica, with the highest diversity observed in Brazil (Carnevali \& Ramírez-Morillo 2003). The only species known from North America (southeastern USA) is $C . d i$ varicata (L.) Ames.

Plants of the genus prefer open areas such as savannas, rocky outcrops or bogs, and they are often found growing in moist, well-drained, sandy, acid soils (Cameron 2003; Carnevali \& RamírezMorillo 2003).

The occurrence of $\mathrm{ca} 13$ Cleistes species has been reported from Colombia, most of them found in lowland and lower montane areas up to $2000 \mathrm{~m}$ a.s.l. (Ortiz Valdivieso \& Uribe Vélez 2007; Szlachetko \& Baranow 2012).

Our recent studies on the orchid flora of southern Colombia revealed the existence of a distinctive Cleistes species which is described here as new. 


\section{DESCRIPTION OF THE NEW SPECIES}

Cleistes cuatrecasasii Kolan. \& Szlach., sp. nov.

Fig. 1

Species similar to Cleistes acuminata (Schltr.) Schltr. from which it differs by having much smaller flowers with subobtuse tepals, a shortly acuminate lip, and different lip callus consisting of two low lamellae running from the base to the lip basal fifth, transforming gradually into serrate lamellae which disappear before the lip apex.

HolotyPE: COLOMBIA, Nariño, Reserva Natural La Planada. A $7 \mathrm{~km}$ de Chucunés, $1^{\circ} 10^{\prime} \mathrm{N} 77^{\circ} 58^{\prime} \mathrm{W}$, alt. 1800 m, 25 Sep. 1989, Olga de Benavides 10720 (PSO).

Plant over $47 \mathrm{~cm}$ tall (lower part missing in holotype). Leaves two, ligulate-lanceolate, acute, $6.0-6.2 \mathrm{~cm}$ long, $1.2-1.4 \mathrm{~cm}$ wide. Flower pale magenta, sepals yellowish rose. Floral bracts up to $46 \mathrm{~mm}$ long, $14 \mathrm{~mm}$ wide, foliaceous, ovatelanceolate, acute. Pedicellate ovary $22 \mathrm{~mm}$ long. Dorsal sepal $40 \mathrm{~mm}$ long, $8 \mathrm{~mm}$ wide, ligulatelanceolate, subobtuse. Lateral sepals $35 \mathrm{~mm}$ long, $7 \mathrm{~mm}$ wide, oblong-lanceolate, subobtuse, somewhat oblique. Petals $33 \mathrm{~mm}$ long, $8 \mathrm{~mm}$ wide, oblong, subobtuse, somewhat oblique. Lip $33 \mathrm{~mm}$ long, $10 \mathrm{~mm}$ wide when spread, ligulate-oblong, shortly acuminate, apex subobtuse, the base truncate, with two clavate projections and two rather low lamellae running from the base to the lip basal fifth, then transforming gradually into serrate low lamellae which disappear before the lip apex. Gynostemium $20 \mathrm{~mm}$ long.

ETYMOLOGY. Named to honor José Cuatrecasas Arumí (1903-1996), an eminent Spanish botanist studying Colombian flora.

DistRIBUTION, HABITAT AND ECOLOGY. Growing terrestrially in the Andean forest at $c a 1800 \mathrm{~m}$ altitude. Flowering in September. The new species is known only from the Pacific slopes of the Western Cordillera, where it was found in the La Planada Nature Reserve located in the Colombian Department of Nariño. The locality of C. cuatrecasasii is situated near the border between Colombia and Ecuador, hence this species is also expected to be found in that country.
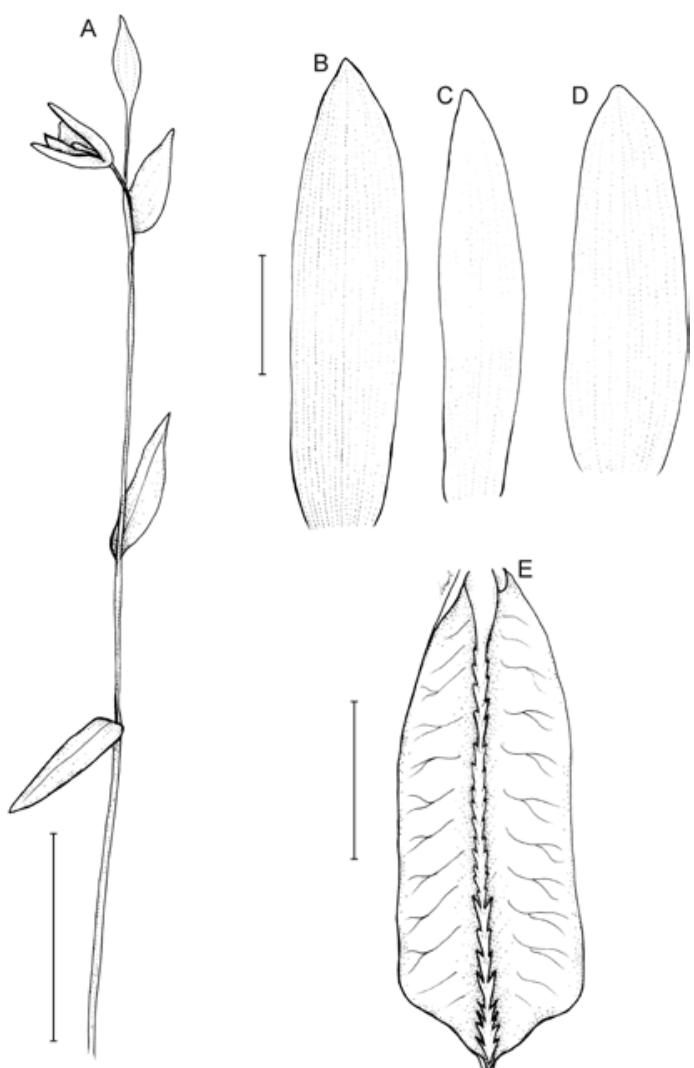

Fig. 1. Cleistes cuatrecasasii Kolan. \& Szlach., sp. nov. A habit, B - dorsal sepal, C - lateral sepal, D - petal, E - lip (drawn by S. Nowak from the holotype). Scale bars: $A=10 \mathrm{~cm}$; $\mathrm{B}-\mathrm{E}=10 \mathrm{~mm}$.

Notes. The new species resembles Cleistes acuminata (Schltr.) Schltr. from which it differs by having smaller leaves (up to $6.2 \mathrm{~cm}$ long vs $14 \mathrm{~cm}$ long), much smaller flowers (sepals 35-40 mm long vs sepals ca $55 \mathrm{~mm}$ ) with subobtuse tepals (vs tepals long acuminate), a shortly acuminate lip (vs lip long acuminate) and lip callus consisting of two rather low lamellae running from the base to the lip basal fifth, then transforming gradually into serrate, low lamellae which disappear before the lip apex (vs two high lamellae running in the basal half of the lip, then gradually transforming into crenulate low lamellae reaching the lip apex).

ACKNOWLEDGEMENTS. The first author thanks Martha Sofía González Insuasti, Curator of PSO, for her kind hospitality and assistance during the visit. We are grateful 
to Sławomir Nowak for preparing the illustration and the anonymous reviewers for helpful remarks on the manuscript. The research described here was supported by the Polish Ministry of Science and Higher Education (research grant no. 8124/B/PO1/2011/40).

\section{REFERENCES}

CAmeron K. 2003. Cleistes. In: A. M. Pridgeon, P. J. CribB, M. W. Chase \& F. N. RASMUSSEN (eds), Genera Orchidacearum, Vanilloideae, pp. 286-289. Oxford University Press, Oxford.

Campacci M. A., Docha N. A., Baptista D. H., Deusvando DE VAscocelos F., CARr G. F., Harding P. \& CASTRONeto V. P. 2011. Generos, especies e hibridos naturais novos. Colet. Orquideas Brasil. 9: 309-356.

CARnevali G. \& Ramírez-Morillo I. 2003. Cleistes. In: P. E. BERRY (ed.), Flora of the Venezuelan Guayana, 7: 278. Missouri Botanical Garden, St. Louis.

Christenson E. A. 1992. Mesoamerican Orchid studies IV: a new Cleistes from Costa Rica. Lindleyana 7: 206-207.

Dressler R.L. \& Dodson C. H. 1960. Classification and phylogeny in the Orchidaceae. Ann. Missouri Bot. Gard. 47: 25-68.

FOLDATS E. 1970. Orchidaceae. In: T. LASSER (ed.), Flora de Venezuela. 15(1): 137-139. Instituto Botanico, Caracas.

GARAY L. A. 1978. Orchidaceae (Cypripedioideae, Orchidoideae, Neottioideae). In: G. HARLing \& B. Sparre (eds), Flora of Ecuador. 9: 1-305. Department of Systematic
Botany, University of Goteborg and Section for Botany, Riksmuseum, Goteborg.

LindLEY J. 1840. The Genera and Species of Orchidaceous Plants. Ridgeway, London.

Ortiz VALdivieso P. \& URIBE VÉLEZ C. 2007. Galería de Orquídeas de Colombia (CD edition). Asociación Bogotana de Orquideología, Bogotá.

PANSARIN E. R. 2004. Cleistes pusilla: a new species from Central Brazil. Kew Bull. 59: 555-558.

PANSARIN E. R. \& BARRos F. 2008. Taxonomic notes on Pogonieae: Cleistesiopsis, a new genus segregated from Cleistes, and description of two new South American species, Cleistes batistana and C. elongata. Kew Bull. 63: 441-448.

SCHUltes R. E. 1960. Native orchids of Trinidad and Tobago. Pergamon, London.

SChweINFurTh C. 1958. Orchidaceae, orchids of Peru. Fieldiana, Bot. 30(1): 1-260.

SZlachetKo D. L. \& BARANOW P. 2012. Four new species of Cleistes (Orchidaceae, Vanilloideae) from Colombia. Ann. Bot. Fenn. 49: 377-382.

SzlachetKo D. L \& RutKowski P. 2000. Gynostemia Orchidalium. 1. Apostasiaceae, Cypripediaceae, Orchidaceae (Thelymitroideae to Vanilloideae). Acta Bot. Fenn. 169: 308 .

Williams L. O., Allen P. H. \& Dressler R. L. 1980. Orchids of Panama: a facsimile reprint of the Orchidaceae. Flora of Panama. 4. Missouri Botanical Garden Press, St. Louis. 